\title{
In vitro modulation of MMP-2 and MMP-9 in adult human sarcoma cell lines by cytokines, inducers and inhibitors
}

\author{
M.W. ROOMI, T. KALINOVSKY, J. MONTERREY, M. RATH and A. NIEDZWIECKI \\ Dr. Rath Research Institute, Santa Clara, CA 95050, USA
}

Received August 12, 2013; Accepted September 13, 2013

DOI: $10.3892 /$ ijo.2013.2113

\begin{abstract}
The highly aggressive adult sarcomas are characterized by high levels of matrix metalloproteinase (MMP)-2 and -9 , which play crucial roles in tumor invasion and metastasis by degradation of the extracellular membrane leading to cancer cell spread to distal organs. We examined the effect of cytokines, mitogens, inducers and inhibitors on MMP-2 and MMP-9 secretion in chondrosarcoma (SW-1353), fibrosarcoma (HT-1080), liposarcoma (SW-872) and synovial sarcoma (SW-982) cell lines. The selected compounds included natural cytokines and growth factors, as well as chemical compounds applied in therapy of sarcoma and natural compounds that have demonstrated anticancer therapeutic potential. MMP-2 and MMP-9 secretions were analyzed by gelatinase zymography following 24-h exposure to the tested agents and quantitated by densitometry. Fibrosarcoma, chondrosarcoma, liposarcoma and synovial sarcoma showed bands corresponding to MMP-2 and MMP-9 with dose-dependent enhancement of MMP-9 with phorbol 12-myristate 13-acetate (PMA) treatment. In chondrosarcoma cells, tumor necrosis factor (TNF)- $\alpha$ had a stimulatory effect on MMP-9 and insignificant effect on MMP-2 and interleukin (IL)-1 $\beta$ stimulated MMP-9 and MMP-2. In fibrosarcoma and liposarcoma cells, TNF- $\alpha$ had a profound stimulatory effect on MMP-9, but no effect on MMP-2 and in synovial sarcoma an inhibitory effect on MMP-2 and no effect on MMP-9. IL-1 $\beta$ had a slight inhibitory effect on fibrosarcoma, liposarcoma and synovial sarcoma MMP-2 and MMP-9 except for MMP-9 in synovial sarcoma which showed slight stimulation. Lipopolysaccharide (LPS) stimulated expression of MMP-2 in fibrosarcoma and chondrosarcoma while inhibited it in liposarcoma. Doxycycline, epigallocatechin gallate and the nutrient mixture inhibited MMP-2 and MMP-9 in all cell lines. Actinomycin-D, cyclo-
\end{abstract}

Correspondence to: Dr Aleksandra Niedzwiecki, Dr. Rath Research Institute, 1260 Memorex Drive, Santa Clara, CA 95050, USA

E-mail: author@drrath.com

Key words: matrix metalloproteinases, chondrosarcoma, fibrosarcoma, liposarcoma, synovial sarcoma, cytokines, inducers, inhibitors hexamide, retinoic acid, and dexamethasone inhibited MMP-2 and -9 in chondrosarcoma and fibrosarcoma cells. Our results show that cytokines, mitogens, inducers and inhibitors have an up or down regulatory effect on MMP-2 and MMP-9 expression in adult sarcoma cell lines, suggesting these agents may be effective strategies to treat these cancers.

\section{Introduction}

According to the American Cancer Society, 11,280 new soft tissue sarcomas would be diagnosed in 2012 (6,110 cases in males and 5,170 cases in females) and 3,900 Americans (2,050 males and 1,850 females) were expected to die of soft tissue sarcomas (1). Fibrosarcoma and liposarcoma are among the most common types of sarcoma in adults (1). Forty percent of primary bone cancers are chondrosarcomas, malignancies of cartilaginous origin, primarily affecting the cartilage cells of femur, arm, pelvis, knee and spine (2) and 4\% of bone cancers are fibrosarcomas, aggressive and highly metastatic cancers of the connective tissue that primarily develops in metaphases of long tubular bones (2,3). Synovial sarcoma, accounting for $<5-10 \%$ of all soft tissue sarcomas, develops in the synovial membrane of the joints, mainly in the lower limbs, but can also occur in the trunk and head/neck (4). Poor prognosis is attributed to both the aggressive metastatic spread characteristic of these cancers and the lack of efficacy in current treatment modalities to prevent or counteract tumor progression. The overall relative 5-year survival rate of people with soft tissue sarcomas is $\sim 50 \%$ according to statistics from the National Cancer Institute (1).

Numerous clinical and experimental studies have demonstrated that elevated levels of MMPs are associated with tumor growth, cancer progression, metastasis and shortened survival in patients $(4,5)$. Among various MMP types, MMP-2 and MMP-9 play pivotal roles in tumor cell invasion and metastasis by degradation of type IV collagen, a major component of the ECM (6-8). MMP-2 (72 kDa) and MMP-9 (92 kDa) are secreted in their latent zymogenic form and cleaved by other MMPs or proteases to yield the activated forms of 68,58 and $54 \mathrm{kDa}$ for MMP-2 and $94 \mathrm{kDa}$ for MMP-9.

MMP activity is regulated by and dependent upon environmental influences from surrounding stroma cells, ECM proteins, systemic hormones and other factors $(6,9,10)$. A variety of cytokines and growth factors, such as transforming growth factor (TGF- $\beta$ ), hepatocyte growth factor (HGF), 
epidermal growth factor (EGF) and tumor necrosis factor (TNF- $\alpha$ ) also control MMP activity $(11,12)$. One of the most potent inducers of cancer cell proliferation is the chemical agent phorbol 12-myristate 13-aceteate (PMA). In addition, activity of MMPs is regulated at multiple levels, including transcription, modulation of messenger RNA half-life (translation), secretion, localization, activation and inhibition (13). There is little information available on the effects of various biological and chemical inducers and inhibitors in sarcomas. Among the few studies available, Rutkowski et al (14) investigated the correlations between serum levels of selected pro-inflammatory, hematopoietic and angiogenic cytokines and soluble cytokine receptors with the clinicopathological features and prognosis in soft tissue sarcoma patients. They found significant correlations of serum cytokine levels with tumor size and grade suggesting cytokines may be directly or indirectly involved in the progression of soft tissue sarcomas.

In this study, we investigated the effects of selected cytokines, inducers and inhibitors affecting cancer cell metabolism on the regulation of MMP-2 and MMP-9 activities in chondrosarcoma, fibrosarcoma, liposarcoma and synovial sarcoma cell lines.

\section{Materials and methods}

Materials. Human adult sarcoma cell lines chondrosarcoma (SW-1353), fibrosarcoma (HT-1080), liposarcoma (SW-872) and synovial sarcoma (SW-982) along with their culture media were obtained from ATCC. Antibiotics, penicillin and fetal bovine serum (FBS), were obtained from Gibco (BRL, Long Island, NY, USA). Twenty-four well tissue culture plates were obtained from Costar (Cambridge, MA, USA). Gelatinase zymography was performed in $10 \%$ Novex pre-cast SDS polyacrylamide gel (Invitrogen Inc.) with $0.1 \%$ gelatin in non-reducing conditions. Interleukin $1 \beta$ (IL-1 $\beta$ ), tumor necrosis factor- $\alpha$ (TNF- $\alpha$ ), PMA, lipopolysaccharide (LPS), doxycycline, epigallocatechin gallate (EGCG), cyclohexamide, actinomycin-D, retinoic acid and dexamethasone, were purchased from Sigma (St. Louis, MO, USA). The nutrient mixture (NM), prepared by VitaTech (Hayward, CA, USA) was composed of the following ingredients in the relative amounts indicated: Vitamin $\mathrm{C}$ (as ascorbic acid and as $\mathrm{Mg}, \mathrm{Ca}$ and palmitate ascorbate) $700 \mathrm{mg}$; L-lysine $1000 \mathrm{mg}$; L-proline $750 \mathrm{mg}$; L-arginine $500 \mathrm{mg}$; N-acetyl cysteine $200 \mathrm{mg}$; standardized green tea extract ( $80 \%$ polyphenol) $1000 \mathrm{mg}$; selenium $30 \mu \mathrm{g}$; copper $2 \mathrm{mg}$; manganese $1 \mathrm{mg}$. All other reagents used were of high quality and were obtained from Sigma, unless otherwise indicated.

Cell cultures. The sarcoma cell lines were grown in their respective media: fibrosarcoma in MEM, chondrosarcoma in DEM, liposarcoma in MEM and synovial sarcoma in DME, supplemented with $10 \%$ FBS, penicillin $(100 \mathrm{U} / \mathrm{ml})$ and streptomycin $(100 \mu \mathrm{g} / \mathrm{ml})$ in $24-w e l l$ tissue culture plates. The cells were plated at a density of $1 \times 10^{5}$ cells $/ \mathrm{ml}$ and grown to confluency in a humidified atmosphere at $5 \% \mathrm{CO}_{2}$ at $37^{\circ} \mathrm{C}$. Serum-supplemented media were removed and the cell monolayer was washed once with PBS and with the recommended serum-free media. The cells were then incubated in $0.5 \mathrm{ml}$ of serum-free medium with various cytokines, mitogens, inducers and inhibitors in triplicates, as indicated: PMA (10, 25, 50, $100 \mathrm{ng} / \mathrm{ml}) ; \mathrm{TNF}-\alpha$ $(0.1,1,10,25 \mathrm{ng} / \mathrm{ml}) ; \mathrm{IL}-1 \beta(0.1,1,10,25 \mathrm{ng} / \mathrm{ml})$; LPS $(10,25$, $50,100 \mu \mathrm{g} / \mathrm{ml}) ; \mathrm{EGCG}(10,25,50,100 \mu \mathrm{M})$ without and with PMA $100 \mathrm{ng} / \mathrm{ml}$; doxycycline $(10,25,50,100 \mu \mathrm{M})$ without and with PMA $100 \mathrm{ng} / \mathrm{ml}$; NM $(10,50,100,500,1000 \mu \mathrm{g} / \mathrm{ml})$ with PMA $100 \mathrm{ng} / \mathrm{ml}$, TNF- $\alpha 10 \mathrm{ng} / \mathrm{ml}$, or IL-1 $\beta 10 \mathrm{ng} / \mathrm{ml}$; retinoic acid $(50 \mu \mathrm{M})$; dexamethasone $(50 \mu \mathrm{M})$; actinomycin-D (2 and $4 \mu \mathrm{g} / \mathrm{ml}$ ); and cyclohexamide ( 2 and $4 \mu \mathrm{g} / \mathrm{ml}$ ). The plates were then returned to the incubator. The conditioned medium from each treatment was collected separately, pooled and centrifuged at $4^{\circ} \mathrm{C}$ for $10 \mathrm{~min}$ at $3000 \mathrm{rpm}$ to remove cells and cell debris. The clear supernatant was collected and used for gelatinase zymography, as described below.

Gelatinase zymography. Gelatinase zymography was utilized because of its high sensitivity to gelatinolytic enzymatic activity and ability to detect both pro and active forms of MMP-2 and MMP-9. Upon renaturation of the enzyme, the gelatinases digest the gelatin in the gel and reveal clear bands against an intensely stained background. Gelatinase zymography was performed in $10 \%$ Novex pre-cast SDS polyacrylamide gel in the presence of $0.1 \%$ gelatin under nonreducing conditions. Culture media $(20 \mu \mathrm{l})$ were mixed with sample buffer and loaded for SDS-PAGE with tris glycine SDS buffer, as suggested by the manufacturer (Novex). Samples were not boiled before electrophoresis. Following electrophoresis the gels were washed twice in $2.5 \%$ Triton X-100 for $30 \mathrm{~min}$ at room temperature to remove SDS. The gels were then incubated at $37^{\circ} \mathrm{C}$ overnight in substrate buffer containing $50 \mathrm{mM}$ Tris- $\mathrm{HCl}$ and $10 \mathrm{mM} \mathrm{CaCl}_{2}$ at $\mathrm{pH} 8.0$ and stained with $0.5 \%$ Coomassie Blue R250 in 50\% methanol and 10\% glacial acetic acid for $30 \mathrm{~min}$ and destained.

Protein standards were run concurrently and approximate molecular weights were determined by plotting the relative mobilities of known proteins. Gelatinase zymograms were scanned using CanoScan 9950F Canon scanner at $300 \mathrm{dpi}$. The intensity of the bands was evaluated using the pixelbased densitometer program Un-Scan-It, version 5.1, 32-bit, by Silk Scientific Corp. (Orem, UT, USA), at a resolution of 1 Scanner Unit (1/100 of an inch for an image that was scanned at $100 \mathrm{dpi}$ ).

\section{Results}

Inducers and cytokines. Table I shows the quantitative densitometry results from the effects of PMA, TNF- $\alpha$, IL- $1 \beta$ and LPS on MMP-2 and MMP-9 expression in chondrosarcoma, fibrosarcoma, liposarcoma and synovial sarcoma cell lines

Effect of PMA, TNF- $\alpha, I L-1 \beta$ and LPS on MMP-2 and $M M P-9$ expression in chondrosarcoma $S W-1353$ cell line. On gelatinase zymography, SW-1353 cells demonstrated strong expression of MMP-2 and slight expression of MMP-9. PMA treatment had no significant effect on expression of MMP-2 but stimulated MMP-9 expression in a dose-dependent manner (linear trend $\mathrm{R}^{2}=0.9673$ ), as shown in Fig. 1 . TNF- $\alpha$ had a stimulatory effect on MMP-9 (linear trend $\mathrm{R}^{2}=0.5135$ ) and insignificant effect on MMP-2. IL-1 $\beta$ stimulated MMP-9 and MMP-2. LPS showed slight stimulation of MMP-2 but no significant effect on MMP-9. 
Table I. Effect of inducers on adult sarcoma MMPs.

\begin{tabular}{|c|c|c|c|c|c|c|c|c|}
\hline & \multicolumn{2}{|c|}{$\begin{array}{l}\text { Chondrosarcoma } \\
\text { (SW-1353) }\end{array}$} & \multicolumn{2}{|c|}{$\begin{array}{c}\text { Fibrosarcoma } \\
(\text { HT-1080) }\end{array}$} & \multicolumn{2}{|c|}{$\begin{array}{l}\text { Liposarcoma } \\
\text { (SW-872) }\end{array}$} & \multicolumn{2}{|c|}{$\begin{array}{l}\text { Synovial sarcoma } \\
\quad(\text { SW-982) }\end{array}$} \\
\hline & MMP-2 (\%) & MMP-9 (\%) & MMP-2 (\%) & MMP-9 (\%) & MMP-2 (\%) & MMP-9 (\%) & MMP-2 (\%) & MMP-9 (\%) \\
\hline \multicolumn{9}{|c|}{ PMA (ng/ml) } \\
\hline Control & 2.9 & 0.1 & 4.2 & 0.1 & 0.7 & 1.2 & 11.9 & 0.0 \\
\hline 10 & 3.8 & 7.0 & 4.5 & 11.7 & 0.9 & 20.9 & 12.4 & 0.0 \\
\hline 25 & 6.6 & 19.0 & 10.5 & 17.1 & 0.2 & 23.1 & ND & ND \\
\hline 50 & 5.1 & 23.1 & 8.5 & 18.0 & 0.6 & 28.0 & 10.0 & 5.0 \\
\hline 100 & 4.1 & 28.3 & 6.3 & 19.1 & 0.6 & 23.7 & 5.6 & 55.1 \\
\hline \multicolumn{9}{|c|}{$\mathrm{TNF}-\alpha(\mathrm{ng} / \mathrm{ml})$} \\
\hline Control & 14.9 & 14.5 & 4.8 & 0.1 & 3.4 & 8.7 & 25.3 & 0.0 \\
\hline 0.1 & 6.0 & 0.2 & 5.6 & 0.3 & 3.9 & 9.1 & 29.9 & 0.0 \\
\hline 1 & 14.9 & 0.3 & 6.2 & 1.1 & 2.2 & 5.1 & 27.5 & 0.0 \\
\hline 10 & 15.4 & 0.5 & 5.7 & 32.0 & 3.6 & 31.8 & 15.4 & 1.8 \\
\hline 25 & 23.8 & 19.8 & 6.0 & 38.1 & 2.7 & 29.5 & ND & ND \\
\hline \multicolumn{9}{|c|}{ IL-1 $\beta(\mathrm{ng} / \mathrm{ml})$} \\
\hline Control & 9.0 & 0.3 & 18.6 & 0.6 & 5.5 & 14.1 & 24.7 & 0.0 \\
\hline 0.1 & 19.3 & 1.2 & 14.6 & 0.2 & 3.8 & 13.0 & 27.1 & 0.0 \\
\hline 1 & 13.8 & 3.5 & 25.4 & 0.9 & 4.2 & 19.7 & 24.7 & 0.0 \\
\hline 10 & 26.8 & 8.1 & 23.4 & 0.7 & 3.3 & 23.0 & 22.4 & 1.1 \\
\hline 25 & 14.8 & 3.2 & 15.3 & 0.5 & 2.3 & 11.0 & ND & ND \\
\hline \multicolumn{9}{|c|}{ LPS $(\mu \mathrm{g} / \mathrm{ml})$} \\
\hline Control & 11.5 & 6.1 & 17.1 & 0.5 & 9.0 & 15.4 & ND & ND \\
\hline 10 & 12.7 & 6.2 & 12.8 & 0.5 & 3.5 & 5.0 & ND & ND \\
\hline 25 & 16.5 & 6.4 & 21.6 & 0.8 & 4.5 & 7.1 & ND & ND \\
\hline 50 & 15.2 & 6.5 & 23.6 & 1.1 & 10.6 & 23.9 & ND & ND \\
\hline 100 & 13.0 & 5.9 & 21.6 & 0.5 & 5.9 & 14.9 & ND & ND \\
\hline
\end{tabular}
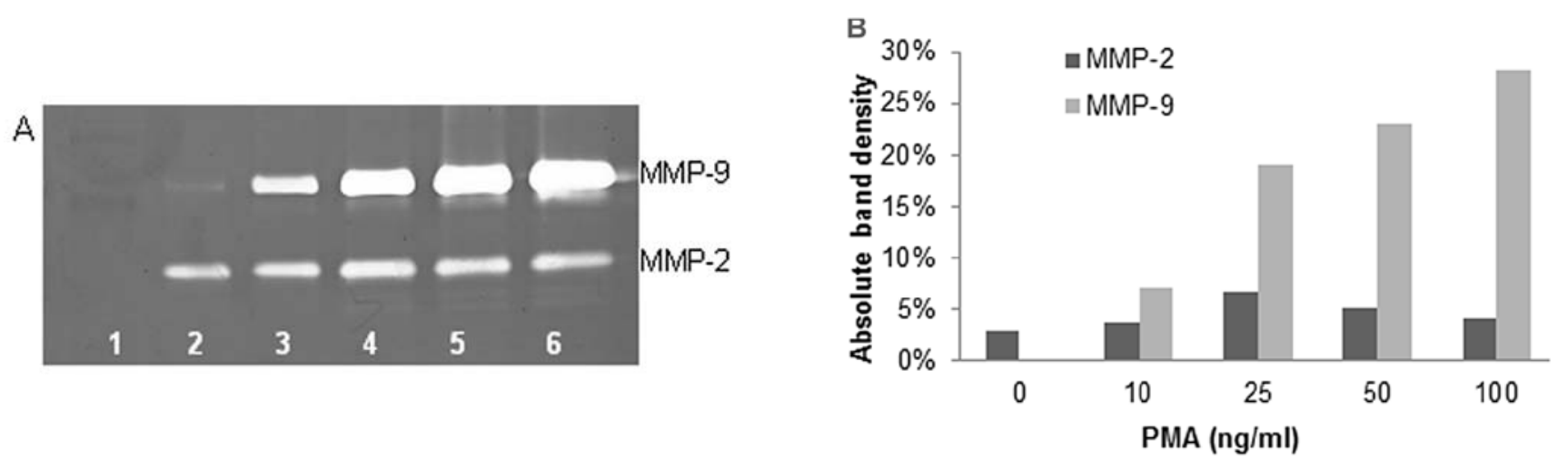

Figure 1. Effect of PMA on chondrosarcoma SW-1353 MMP-2 and -9 secretions. Gelatinase zymogram (A) and densitometry analysis (B) of SW-1353 of MMP-2 and -9 expression levels. Lane 1, Markers; 2, Control; 3-6, 10, 25, 50, 100 ng/ml PMA.

Effect of PMA, TNF- $\alpha, I L-1 \beta$ and LPS on MMP-2 and MMP-9 expression in fibrosarcoma HT-1080 cell line. On gelatinase zymography, HT-1080 cells demonstrated strong expression of MMP-2 inactive and faint MMP-2 active, both greater than MMP-9. PMA treatment strongly stimulated MMP-9 expression in a dose-dependent manner (linear trend $\mathrm{R}^{2}=0.7952$ ) and slightly enhanced MMP-2 active and inhibited MMP-2 inactive, as shown in Fig. 2. TNF- $\alpha$ had a strong stimulatory dose-dependent effect on MMP-9 and a slight enhancement of MMP-2. IL-1 $\beta$ slightly stimulated MMP-9 and had no discernible effect on MMP-2. LPS showed slight stimulation of MMP-2 but no significant effect on MMP-9. 

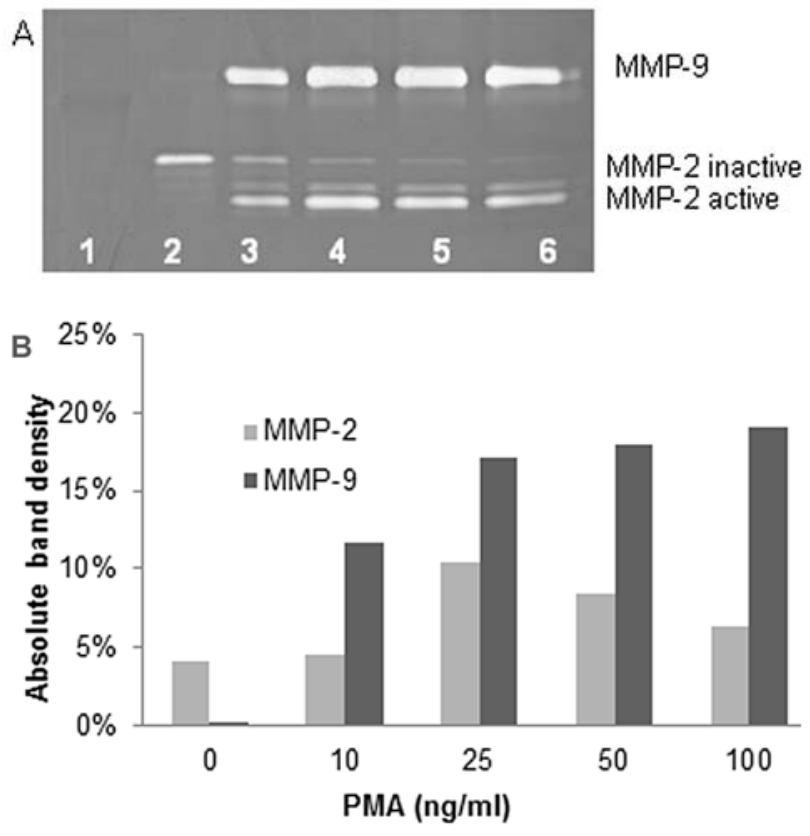

Figure 2. Effect of PMA on fibrosarcoma HT-1080 MMP-2 and -9 secretions. Gelatinase zymogram (A) and densitometry analysis (B) of HT-1080 MMP-2 and -9 expression levels. Lane 1, Markers; 2, Control; 3-6, 10, 25, $50,100 \mathrm{ng} / \mathrm{ml}$ PMA.
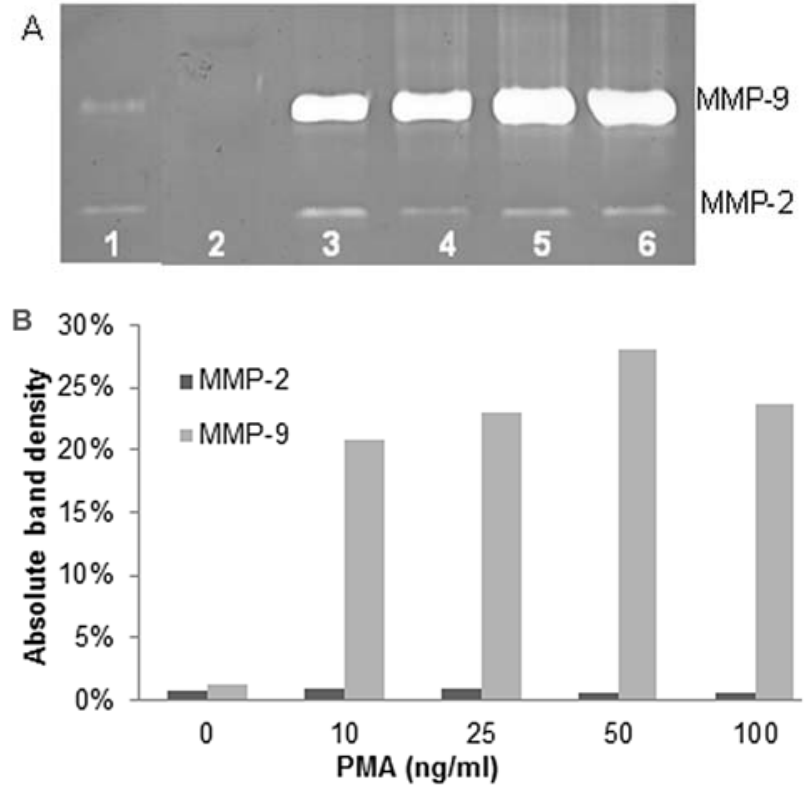

Figure 3. Effect of PMA on liposarcoma SW-872 MMP-2 and -9 secretions. Gelatinase zymogram (A) and densitometry analysis (B) of SW-872 MMP-2 and -9 expression levels. Lane 1, Markers; 2, Control; 3-6, 10, 25, $50,100 \mathrm{ng} / \mathrm{ml}$ PMA.

Effect of PMA, TNF- $\alpha, I L-1 \beta$ and LPS on MMP-2 and MMP-9 expression in liposarcoma $S W-872$ cell line. On gelatinase zymography, SW-872 cells demonstrated MMP-2 and MMP-9 expression. PMA treatment strongly stimulated MMP-9 expression in a dose-dependent manner (linear trend $\mathrm{R}^{2}=0.617$ ) but had no significant effect on MMP-2, as shown in Fig. 3. TNF- $\alpha$ had a strong stimulatory dose-dependent effect on MMP-9 (linear trend $\mathrm{R}^{2}=0.6358$ ) and a slight reduction in MMP-2.
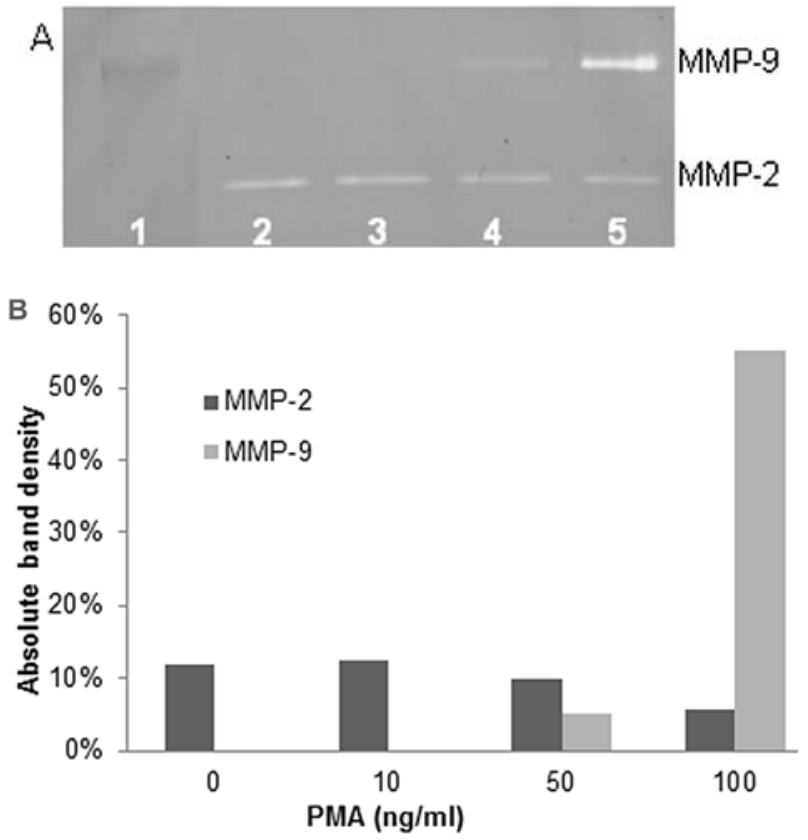

Figure 4. Effect of PMA on synovial sarcoma SW-982 MMP-2 and -9 secretions. Gelatinase zymogram (A) and densitometry analysis (B) of SW-982 MMP-2 and -9 expression levels. Lane 1, Markers; 2, Control; 3-5, 10, 50, $100 \mathrm{ng} / \mathrm{ml}$ PMA.

IL-1 $\beta$ slightly stimulated MMP-9 expression at 1 and $10 \mathrm{ng} / \mathrm{ml}$, then inhibited it at $25 \mathrm{ng} / \mathrm{ml}$ and inhibited MMP-2 in dosedependent manner (linear trend $\mathrm{R}^{2}=0.865$ ). LPS showed slight dose-dependent inhibition in MMP-2, except at $50 \mathrm{ng} / \mathrm{ml}$, but no significant effect on MMP-9.

Effect of PMA, TNF- $\alpha, I L-1 \beta$ and LPS on MMP-2 and $M M P-9$ expression in synovial sarcoma SW-982 cell line. On gelatinase zymography, SW-982 cells demonstrated moderate MMP-2 and no MMP-9 expression. PMA treatment strongly stimulated MMP-9 expression in a dose-dependent manner (linear trend $\mathrm{R}^{2}=0.672$ ) and slightly inhibited MMP-2 expression (linear trend $\mathrm{R}^{2}=0.797$ ), as shown in Fig. 4. TNF- $\alpha$ had a moderate inhibitory dose-dependent effect on MMP-2 (linear trend $\mathrm{R}^{2}=0.425$ ) and a slight stimulatory effect on MMP-9 at the highest dose tested, $10 \mathrm{ng} / \mathrm{ml}$ (linear trend $\mathrm{R}^{2}=0.425$ ). IL- $1 \beta$ had no significant effect on MMP-2 or MMP-9 expression. The effects of LPS were not determined.

Chemical inhibitors. Table II shows the quantitative densitometry results from the effects of chemical inhibitors doxycycline, dexamethasone, actinomycin-D and cyclohexamide on MMP-2 and MMP-9 expression in chondrosarcoma, fibrosarcoma, liposarcoma and synovial sarcoma cell lines

Effect of chemical inhibitors: doxycycline, dexamethasone, actinomycin-D and cyclohexamide on MMP-2 and MMP-9 expression in chondrosarcoma SW-1353 cell line. On gelatinase zymography, SW-1353 cells demonstrated strong expression of MMP-2 and slight expression of MMP-9, with enhanced MMP-9 expression with PMA (100 ng/ml) treatment. Doxycycline with and without PMA $(100 \mathrm{ng} / \mathrm{ml})$ treatment showed dose-dependent inhibition of MMP-2 and 
Table II. Effect of chemical inhibitors on adult sarcoma MMPs.

\begin{tabular}{|c|c|c|c|c|c|c|c|c|}
\hline & \multicolumn{2}{|c|}{$\begin{array}{l}\text { Chondrosarcoma } \\
\text { (SW-1353) }\end{array}$} & \multicolumn{2}{|c|}{$\begin{array}{l}\text { Fibrosarcoma } \\
\text { (HT-1080) }\end{array}$} & \multicolumn{2}{|c|}{$\begin{array}{l}\text { Liposarcoma } \\
\text { (SW-872) }\end{array}$} & \multicolumn{2}{|c|}{$\begin{array}{l}\text { Synovial sarcoma } \\
\quad(\text { SW-982) }\end{array}$} \\
\hline & MMP-2 (\%) & MMP-9 (\%) & MMP-2 (\%) & MMP-9 (\%) & MMP-2 (\%) & MMP-9 (\%) & MMP-2 (\%) & MMP-9 (\%) \\
\hline \multicolumn{9}{|c|}{ Doxycycline $(\mu \mathrm{M})$} \\
\hline Control & 35.6 & 4.5 & 26.3 & 5.5 & 8.3 & 12.7 & ND & ND \\
\hline 10 & 35.4 & 4.2 & 35.6 & 3.4 & 10.0 & 20.7 & ND & ND \\
\hline 25 & 11.1 & 1.8 & 22.7 & 0.0 & 8.8 & 28.4 & ND & ND \\
\hline 50 & 4.9 & 1.9 & 6.5 & 0.0 & 1.8 & 7.3 & ND & ND \\
\hline 100 & 0.4 & 0.2 & 0.0 & 0.0 & 0.1 & 1.8 & ND & ND \\
\hline \multicolumn{9}{|c|}{ Doxycycline $(\mu \mathrm{M})$ with PMA $(100 \mathrm{ng} / \mathrm{ml})$} \\
\hline Control & 0.9 & 26.8 & 1.4 & 17.7 & 33.5 & 2.0 & ND & ND \\
\hline 10 & 1.2 & 26.1 & 8.9 & 24.9 & 16.8 & 0.3 & ND & ND \\
\hline 25 & 1.1 & 22.3 & 5.9 & 17.4 & 1.8 & 0.0 & ND & ND \\
\hline 50 & 2.0 & 18.5 & 6.0 & 17.3 & 92.8 & 6.6 & ND & ND \\
\hline 100 & 0.1 & 1.1 & 0.1 & 0.4 & 0.0 & 0.0 & ND & ND \\
\hline \multicolumn{9}{|c|}{ Dexamethasone $(\mu \mathrm{M})$} \\
\hline Control & 43.4 & 7.3 & 61.8 & 0.0 & 24.6 & 66.4 & ND & ND \\
\hline 100 & 45.7 & 3.6 & 38.2 & 0.0 & 3.9 & 5.0 & ND & ND \\
\hline \multicolumn{9}{|c|}{ Actinomycin-D $(\mu \mathrm{g} / \mathrm{ml})$} \\
\hline Control & 42.5 & 13.6 & 39.1 & 0.0 & ND & ND & ND & ND \\
\hline 2 & 24.3 & 3.2 & 32.4 & 0.0 & ND & ND & ND & ND \\
\hline 4 & 22.9 & 2.7 & 28.5 & 0.0 & ND & ND & ND & ND \\
\hline \multicolumn{9}{|c|}{ Cyclohexamide $(\mu \mathrm{g} / \mathrm{ml})$} \\
\hline Control & 80.5 & 13.6 & ND & ND & ND & ND & ND & ND \\
\hline 2 & 3.9 & 0.0 & ND & ND & ND & ND & ND & ND \\
\hline 4 & 2.0 & 0.0 & ND & ND & ND & ND & ND & ND \\
\hline
\end{tabular}

MMP-9 (linear trends $\mathrm{R}^{2}=0.894$ and 0.910 , respectively). MMP-2 was inhibited by $99 \%$ and MMP-9 by $96 \%$ at $100 \mu \mathrm{M}$ doxycycline compared to control; PMA-treated SW-1353 showed dose-dependent inhibition of MMP-9 $\left(\mathrm{R}^{2}=0.785\right)$ with doxycycline treatment compared to control and no significant change in MMP-2. Actinomycin-D showed dose-dependent inhibition of both MMP-2 and -9 (linear trends $\mathrm{R}^{2}=0.804$ and 0.785 , respectively). Cyclohexamide showed dose-dependent inhibition of both MMP-2 and -9 (linear trends $\mathrm{R}^{2}=0.768$ and 0.750 , respectively). Dexamethasone $50 \mu \mathrm{M}$ demonstrated no effect on MMP-2 but inhibition of MMP-9.

Effect of chemical inhibitors: doxycycline, dexamethasone, actinomycin-D and cyclohexamide on MMP-2 and MMP-9 expression in fibrosarcoma HT-1080 cell line. On gelatinase zymography, normal HT-1080 cells demonstrated strong expression of MMP-2 with PMA-induced expression of MMP-9. Doxycycline treatment of HT-1080 cells showed dosedependent inhibition of MMP-2 and MMP-9 (linear trends $\mathrm{R}^{2}=0.780$ and 0.798 , respectively). PMA-treated HT-1080 showed dose-dependent inhibition of MMP-9 $\left(\mathrm{R}^{2}=0.543\right)$ with doxycycline treatment compared to control and no significant change in MMP-2. Actinomycin-D showed dose-dependent inhibition of MMP-2 (linear trend $\mathrm{R}^{2}=0.978$ ). Dexamethasone $50 \mu \mathrm{M}$ demonstrated no effect on MMP-9 but inhibited MMP-2 by $38 \%$. The effect of cyclohexamide was not determined.

Effect of chemical inhibitors: doxycycline, dexamethasone, actinomycin-D and cyclohexamide on MMP-2 and MMP-9 expression in liposarcoma $\mathrm{SW}-872$ cell line. On gelatinase zymography, normal SW-872 cells demonstrated MMP-2 and MMP-9 expression. Doxycycline treatment of SW-872 cells showed enhanced secretion of MMP-9 at 10 and $25 \mu \mathrm{M}$ and inhibition of MMP-9 at 50 and $100 \mu \mathrm{M}$. MMP-2 expression was not appreciably affected at lower concentrations of doxycycline, but was significantly inhibited at 50 and $100 \mu \mathrm{M}$ (linear trend $\mathrm{R}^{2}=0.739$ ). PMA-treated $\mathrm{SW}-872$ cells showed dose-dependent inhibition of MMP-9 $\left(\mathrm{R}^{2}=0.922\right)$ with doxycycline treatment compared to control and no significant change in MMP-2. Dexamethasone $50 \mu \mathrm{M}$ inhibited SW-873 secretion of MMP- 2 by $84 \%$ and MMP-9 by $99 \%$. The effects of cyclohexamide and actinomycin-D were not determined.

Effect of chemical inhibitors doxycycline, dexamethasone, actinomycin-D and cyclohexamide on MMP-2 and MMP-9 expression in synovial sarcoma $S W-982$ cell line. On gelatinase 

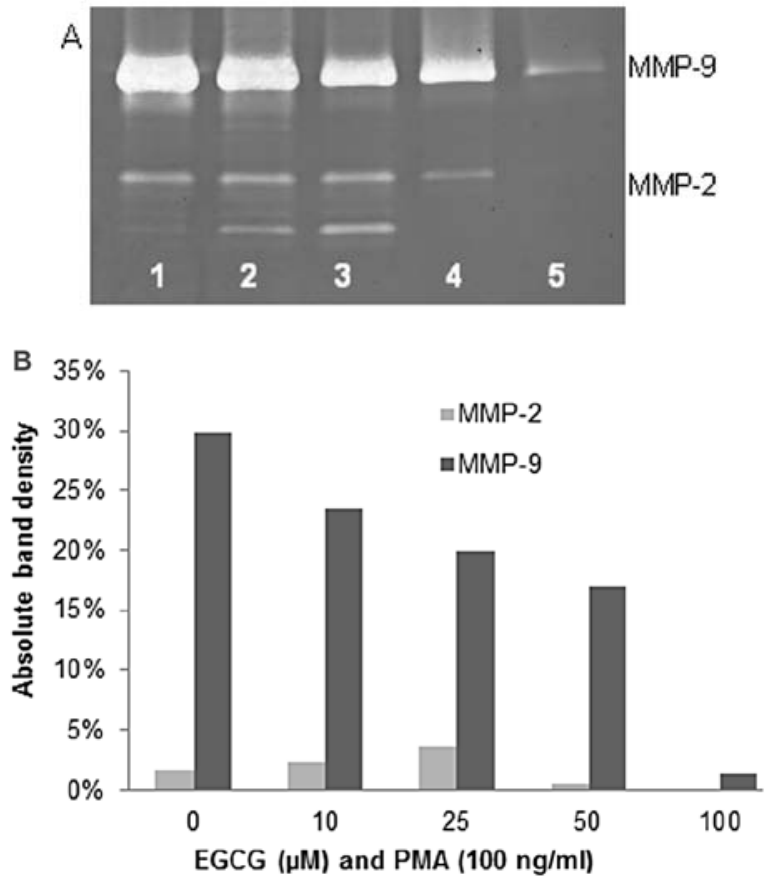

Figure 5. Effect of EGCG on PMA-treated chondrosarcoma SW-1353 MMP-2 and -9 secretions. Gelatinase zymogram (A) and densitometry analysis (B) of SW-1353 MMP-2 and -9 expression levels. Lane 1, Control (100 ng/ml PMA); 2-5, 10, 25, 50, $100 \mu$ M EGCG with PMA (100 ng/ml).

A
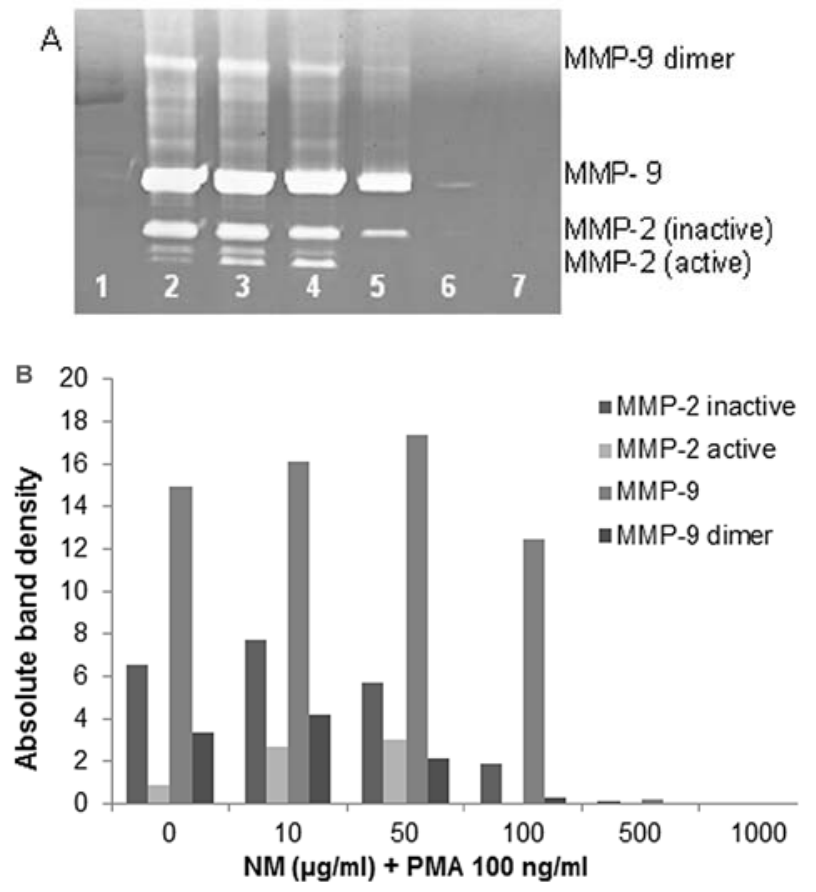

Figure 6. Effect of NM on PMA-treated chondrosarcoma SW-1353 MMP-2 and -9 secretions. Gelatinase zymogram (A) and densitometry analysis (B) of SW-1353 MMP-2 and -9 expression levels. Lane 1, Markers; 2, Control (100 ng/ml PMA); 3-7, 10, 50, 100,500, $1000 \mu \mathrm{g} / \mathrm{ml} \mathrm{NM}$ with PMA (100 ng/ml).

zymography, normal SW-982 cells demonstrated strong expression of MMP-2 and undetectable level of MMP-9. The effects of doxycycline, actinomycin-D, dexamethasone, cyclohexamide and retinoic acid on SW-982 cell expression of MMP-2 and -9 were not determined.
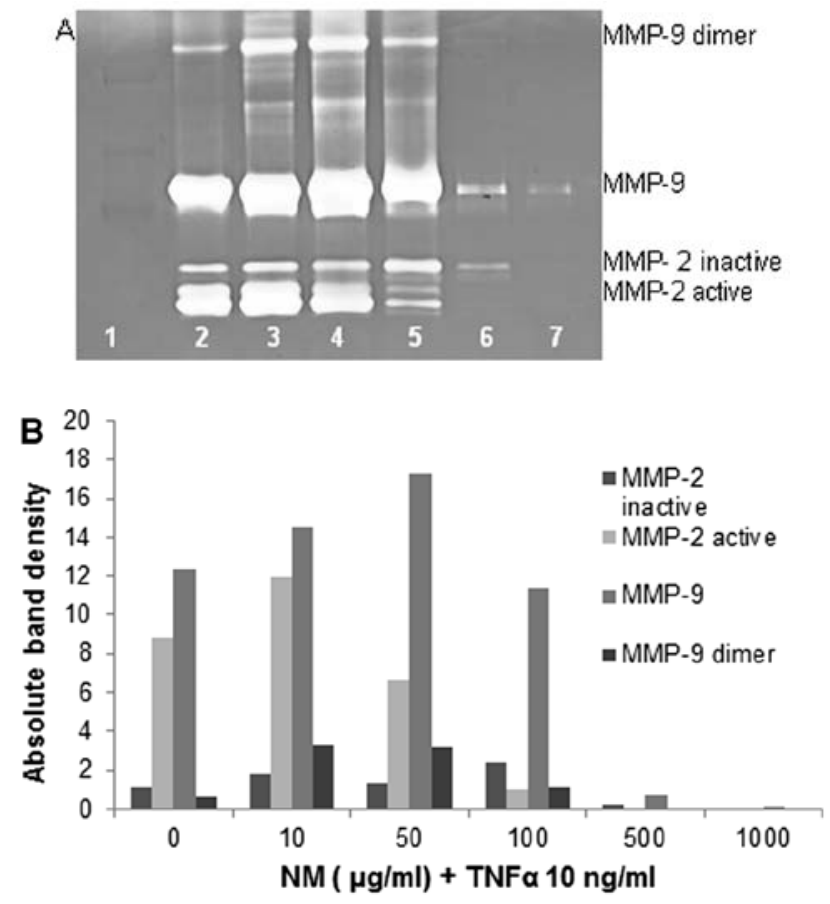

Figure 7. Effect of NM on TNFa-treated chondrosarcoma SW-1353 MMP-2 and -9 secretions. Gelatinase zymogram (A) and densitometry analysis (B) of SW-1353 MMP-2 and -9 expression levels. Lane 1, Markers; 2, Control $(10 \mathrm{ng} / \mathrm{ml} \mathrm{TNF} \alpha) ; 3-7,10,50,100,500,1000 \mu \mathrm{g} / \mathrm{ml} \mathrm{NM}$ with TNF $\alpha(10 \mathrm{ng} / \mathrm{ml})$.

Natural inhibitors. Table III shows the quantitative densitometry results from the effects of natural inhibitors EGCG, the NM and retinoic acid on MMP-2 and MMP-9 expression in chondrosarcoma, fibrosarcoma, liposarcoma and synovial sarcoma cell lines.

Effect of EGCG, nutrient mixture and retinoic acid on MMP-2 and MMP-9 expression in chondrosarcoma SW-1353 cell line treated with inducers. On gelatinase zymography, SW-1353 cells demonstrated strong expression of MMP-2 and slight expression of MMP-9. EGCG inhibited MMP-9 and MMP-2 in a dose-dependent manner, with total inhibition of MMP-2 and 95\% inhibition of MMP-9 at $100 \mu \mathrm{M}$ (linear trends $\mathrm{R}^{2}=0.809$ and 0.933 , respectively). NM inhibited MMP secretion in a dose-dependent manner with virtual total inhibition of MMP-9 at $500 \mu \mathrm{g} / \mathrm{ml}$ (linear trend $\mathrm{R}^{2}=0.713$ ) and MMP-2 at $1000 \mu \mathrm{g} / \mathrm{ml}$ (linear trend $\left.\mathrm{R}^{2}=0.860\right)$. PMA $(100 \mathrm{ng} / \mathrm{ml})$ treatment profoundly enhanced MMP-9 expression. EGCG inhibited MMP-9 and MMP-2 in a dose-dependent manner, with total inhibition of MMP-9 and 96\% inhibition of MMP-2 at $100 \mu \mathrm{M}$ (linear trends $\mathrm{R}^{2}=0.892$ and 0.336 , respectively), as shown in Fig. 5. NM demonstrated dose-dependent inhibition of MMP-2 and MMP-9 expression levels of PMA-treated SW-1353 total block of MMP-2 and virtually total inhibition of MMP-9 secretion at $1000 \mu \mathrm{g} / \mathrm{ml}$ (linear trends $\mathrm{R}^{2}=0.831$ and 0.833 , respectively), as shown in Fig. 6. SW-1353 cells treated with TNF- $\alpha(10 \mathrm{ng} / \mathrm{ml})$ showed strong expression levels of MMP-9 and MMP-2. TNF- $\alpha$-treated cells showed slight stimulation of MMP-2 and -9 at low concentrations of $\mathrm{NM}$ and strong inhibition at concentrations of NM $100 \mu \mathrm{g} / \mathrm{ml}$ and higher, with linear trends $\mathrm{R}^{2}=0.796$ and 0.641 , respectively, as shown in Fig. 7. SW-1353 cells treated with IL-1 $\beta$ 
Table III. Effect of natural inhibitors on adult sarcoma MMPs.

\begin{tabular}{|c|c|c|c|c|c|c|c|c|}
\hline & \multicolumn{2}{|c|}{$\begin{array}{l}\text { Chondrosarcoma } \\
\text { (SW-1353) }\end{array}$} & \multicolumn{2}{|c|}{$\begin{array}{c}\text { Fibrosarcoma } \\
\text { (HT-1080) }\end{array}$} & \multicolumn{2}{|c|}{$\begin{array}{l}\text { Liposarcoma } \\
\text { (SW-872) }\end{array}$} & \multicolumn{2}{|c|}{$\begin{array}{c}\text { Synovial sarcoma } \\
\quad(\text { SW-982) }\end{array}$} \\
\hline & MMP-2 (\%) & MMP-9 (\%) & MMP-2 (\%) & MMP-9 (\%) & MMP-2 (\%) & MMP-9 (\%) & MMP-2 (\%) & MMP-9 (\%) \\
\hline \multicolumn{9}{|c|}{$\mathrm{EGCG}(\mu \mathrm{M})$} \\
\hline Control & 23.9 & 9.5 & 30.6 & 0.0 & 19.7 & 25.6 & 56.5 & 0.0 \\
\hline 10 & 30.7 & 8.7 & 45.6 & 0.0 & 16.1 & 27.9 & 43.5 & 0.0 \\
\hline 25 & 17.6 & 4.6 & 23.9 & 0.0 & 7.0 & 3.7 & 0.0 & 0.0 \\
\hline 50 & 3.8 & 0.3 & 0.0 & 0.0 & 0.0 & 0.0 & 0.0 & 0.0 \\
\hline 100 & 1.0 & 0.0 & 0.0 & 0.0 & 0.0 & 0.0 & 0.0 & 0.0 \\
\hline \multicolumn{9}{|c|}{ EGCG $(\mu \mathrm{M})$ with PMA $(100 \mathrm{ng} / \mathrm{ml})$} \\
\hline Control & 1.7 & 29.8 & 2.4 & 22.0 & 1.7 & 64.4 & 8.8 & 24.8 \\
\hline 10 & 2.4 & 23.5 & 6.4 & 54.2 & 0.1 & 20.8 & 6.7 & 56.2 \\
\hline 25 & 3.6 & 20.0 & 1.4 & 11.8 & 0.2 & 10.9 & 0.0 & 0.0 \\
\hline 50 & 0.6 & 17.0 & 0.0 & 1.9 & 0.0 & 1.8 & 0.0 & 0.0 \\
\hline 100 & 0.0 & 1.4 & 0.0 & 0.0 & 0.0 & 0.2 & 0.0 & 0.0 \\
\hline \multicolumn{9}{|c|}{ Nutrient mixture $(\mu \mathrm{g} / \mathrm{ml})$} \\
\hline Control & 23.8 & 7.2 & 19.4 & 5.4 & 15.6 & 16.3 & 39.4 & 0.7 \\
\hline 10 & 27.8 & 2.1 & 22.5 & 6.3 & 17.7 & 17.3 & 38.1 & 0.0 \\
\hline 50 & 23.4 & 1.5 & 17.5 & 8.4 & 13.7 & 10.4 & 19.2 & 0.0 \\
\hline 100 & 12.0 & 0.7 & 10.1 & 7.9 & 7.0 & 1.9 & 2.6 & 0.0 \\
\hline 500 & 1.4 & 0.0 & 1.1 & 1.2 & 0.1 & 0.0 & 0.0 & 0.0 \\
\hline 1000 & 0.1 & 0.0 & 0.1 & 0.2 & 0.0 & 0.0 & 0.0 & 0.0 \\
\hline \multicolumn{9}{|c|}{ Nutrient mixture $(\mu \mathrm{g} / \mathrm{ml})$ with PMA (100 ng/ml) } \\
\hline Control & 5.8 & 22.5 & 12.6 & 13.2 & 4.7 & 24.4 & 33.9 & 8.6 \\
\hline 10 & 7.4 & 23.0 & 12.9 & 13.8 & 6.1 & 25.2 & 35.6 & 3.9 \\
\hline 50 & 2.9 & 18.6 & 6.2 & 12.9 & 3.5 & 20.2 & 16.4 & 0.2 \\
\hline 100 & 1.4 & 17.5 & 8.0 & 13.9 & 0.6 & 14.4 & 1.4 & 0.0 \\
\hline 500 & 0.1 & 0.8 & 0.2 & 6.0 & 0.0 & 0.8 & 0.0 & 0.0 \\
\hline 1000 & 0.0 & 0.1 & 0.0 & 0.3 & 0.0 & 0.0 & 0.0 & 0.0 \\
\hline \multicolumn{9}{|c|}{ Nutrient mixture $(\mu \mathrm{g} / \mathrm{ml})$ with TNF- $\alpha(10 \mathrm{ng} / \mathrm{ml})$} \\
\hline Control & 9.9 & 12.4 & 16.5 & 13.4 & ND & ND & ND & ND \\
\hline 10 & 13.8 & 14.5 & 21.0 & 15.8 & ND & ND & ND & ND \\
\hline 50 & 7.9 & 17.3 & 13.8 & 9.0 & ND & ND & ND & ND \\
\hline 100 & 3.4 & 11.4 & 5.18 & 1.74 & ND & ND & ND & ND \\
\hline 500 & 0.2 & 0.7 & 0.69 & 0.0 & ND & ND & ND & ND \\
\hline 1000 & 0.0 & 0.15 & 0.02 & 0.0 & ND & ND & ND & ND \\
\hline \multicolumn{9}{|c|}{ Nutrient mixture $(\mu \mathrm{g} / \mathrm{ml})$ with IL-1 $\beta(10 \mathrm{ng} / \mathrm{ml})$} \\
\hline Control & 15.3 & 0.85 & 30.3 & 7.15 & ND & ND & ND & ND \\
\hline 10 & 24.3 & 2.1 & 28.7 & 7.0 & ND & ND & ND & ND \\
\hline 50 & 26.9 & 4.2 & 16.0 & 3.8 & ND & ND & ND & ND \\
\hline 100 & 24.9 & 0.7 & 6.9 & 0.0 & ND & ND & ND & ND \\
\hline 500 & 0.57 & 0.13 & 0.15 & 0.0 & ND & ND & ND & ND \\
\hline 1000 & 0.0 & 0.0 & 0.0 & 0.0 & ND & ND & ND & ND \\
\hline \multicolumn{9}{|c|}{ Retinoic acid $(\mu \mathrm{M})$} \\
\hline Control & 81.6 & 13.9 & ND & ND & ND & ND & ND & ND \\
\hline 50 & 4.5 & 0.0 & ND & ND & ND & ND & ND & ND \\
\hline
\end{tabular}



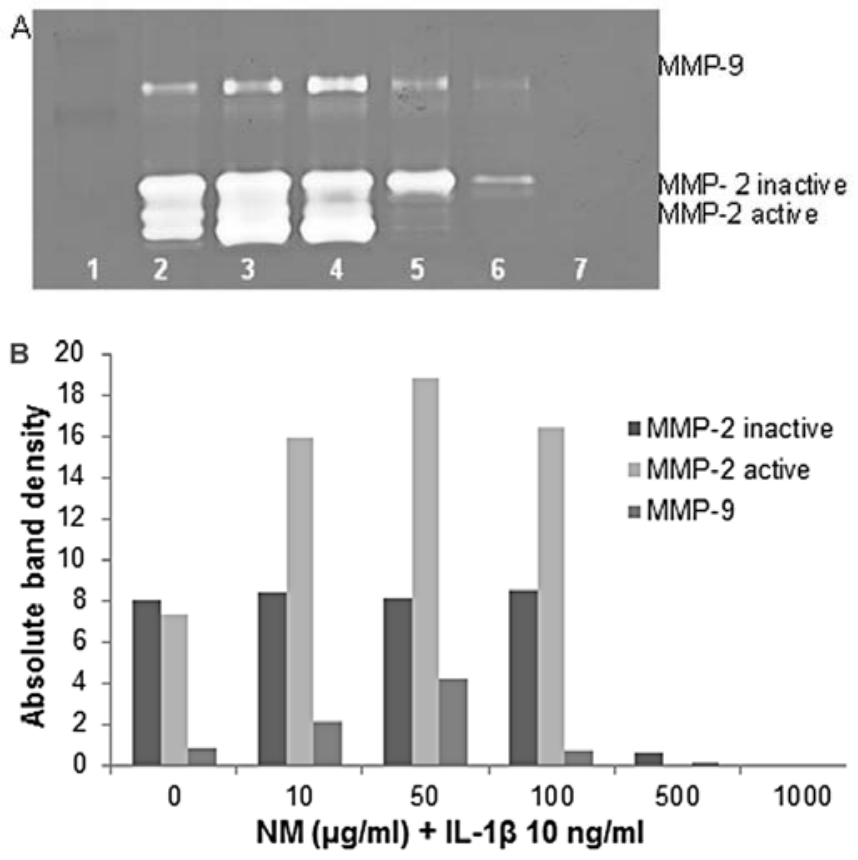

Figure 8. Effect of NM on IL-1 $\beta$-treated chondrosarcoma SW-1353 MMP-2 and -9 secretions. Gelatinase zymogram (A) and densitometry analysis (B) of SW-1353 MMP-2 and -9 expression levels. Lane 1, Markers; 2, Control $(10 \mathrm{ng} / \mathrm{ml} \mathrm{IL}-1 \beta) ; 3-7,10,50,100,500,1000 \mu \mathrm{g} / \mathrm{ml} \mathrm{NM}$ with IL-1 $\beta(10 \mathrm{ng} / \mathrm{ml})$.
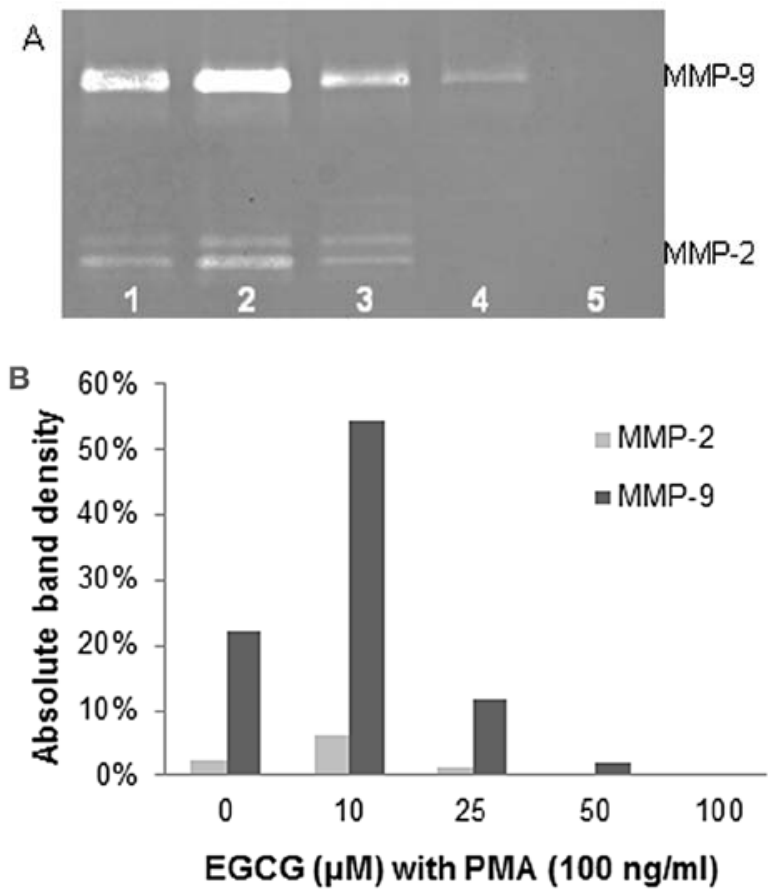

Figure 9. Effect of EGCG on PMA-treated fibrosarcoma HT-1080 MMP-2 and -9 secretions. Gelatinase zymogram (A) and densitometry analysis (B) of HT-1080 MMP-2 and -9 expression levels. Lane 1, Control (100 ng/ml PMA); 2-5, 10, 25, 50, $100 \mu \mathrm{M}$ EGCG with PMA (100 ng/ml).

(10 ng/ml) showed strong expression of MMP-9 and slight expression of MMP-2. NM treatment of IL-1 $\beta$-treated cells showed enhanced expression of both MMPs at low concentrations of NM and strong inhibition of both MMP-2 and MMP-9 at concentrations of NM $100 \mu \mathrm{g} / \mathrm{ml}$ and higher, as shown in
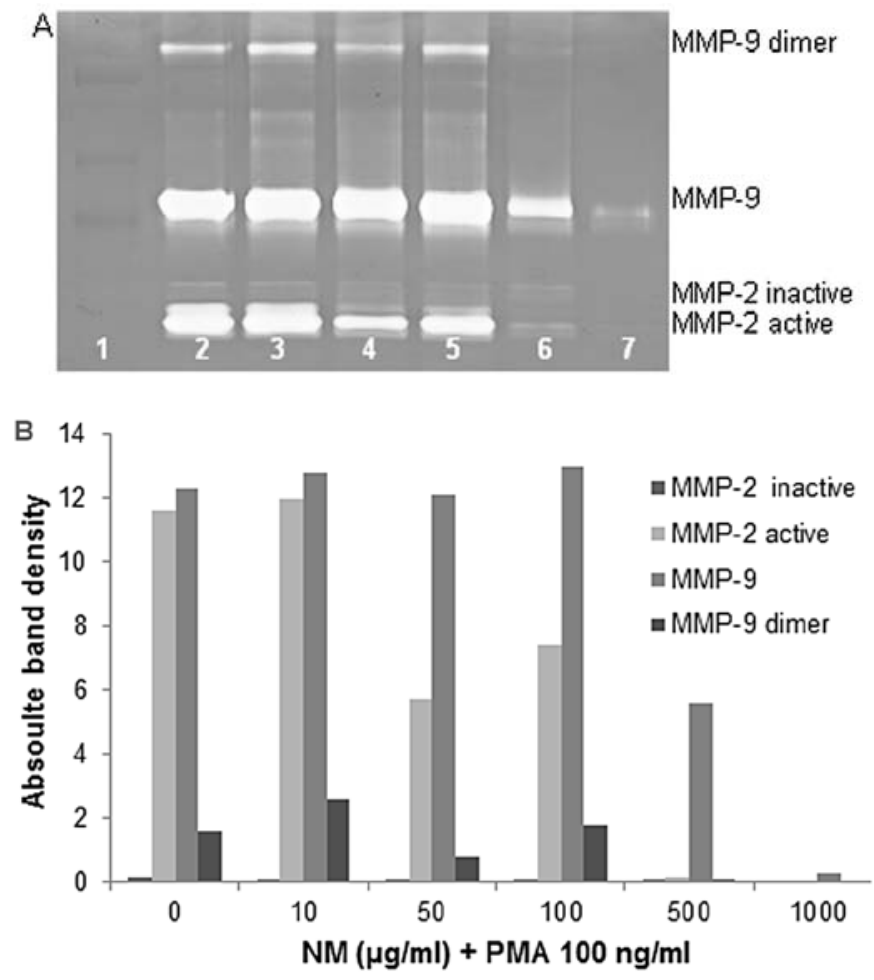

Figure 10. Effect of NM on PMA-treated fibrosarcoma HT-1080 MMP-2 and -9 secretions. Gelatinase zymogram (A) and densitometry analysis (B) of HT-1080 MMP-2 and -9 expression levels. Lane 1, Markers; 2, Control (100 ng/ml PMA); 3-7, 10, 50, 100, 500, $1000 \mu \mathrm{g} / \mathrm{ml} \mathrm{NM} \mathrm{with} \mathrm{PMA}$ (100 ng/ml).

Fig. 8. Retinoic acid showed strong inhibition of MMP-2 and MMP-9 at the dose tested $(50 \mu \mathrm{M})$.

Effect of EGCG, the nutrient mixture and retinoic acid on MMP-2 and MMP-9 expression in fibrosarcoma HT-1080 cell line treated with inducers. On gelatinase zymography, normal HT-1080 cells demonstrated strong expression of MMP-2 with PMA-induced expression of MMP-9. EGCG inhibited MMP-2 in a dose-dependent manner, with linear trend $\mathrm{R}^{2}=0.720$; PMA-treated HT-1080 cells showed MMP-2 and induced MMP-9 expression, which were inhibited in a dose-dependent manner, with linear trends $\mathrm{R}^{2}=0.452$ and 0.475 , respectively, as shown in Fig. 9. NM inhibited secretion of MMP-2 and MMP-9 by uninduced HT-1080 cells in a dose-dependent manner, with linear trends $\mathrm{R}^{2}=0.510$ and 0.546 , respectively. $\mathrm{NM}$ showed dose-dependent inhibition of MMP-2 and -9 expression in PMA-treated cells with linear trends $\mathrm{R}^{2}=0.866$ and 0.678 , respectively, as shown in Fig. 10. HT-1080 cells treated with TNF- $\alpha$ (10 ng/ml) showed strong expression levels of MMP-9 and MMP-2. TNF- $\alpha$-treated cells showed slight stimulation of MMP-2 and -9 at low concentrations of NM and strong inhibition at concentrations of NM $100 \mu \mathrm{g} / \mathrm{ml}$ and higher, with linear trends $\mathrm{R}^{2}=0.880$ and 0.855 , respectively, as shown in Fig. 11. HT-1080 cells treated with IL-1 $\beta(10 \mathrm{ng} / \mathrm{ml})$ showed a strong expression of MMP-9 greater than MMP-2. NM treatment of IL-1 $\beta$-treated cells showed dose-dependent inhibition of both MMP-2 and MMP-9, with linear trends $\mathrm{R}^{2}=0.934$ and 0.861 , respectively, as shown in Fig. 12. The effect of retinoic acid was not determined. 

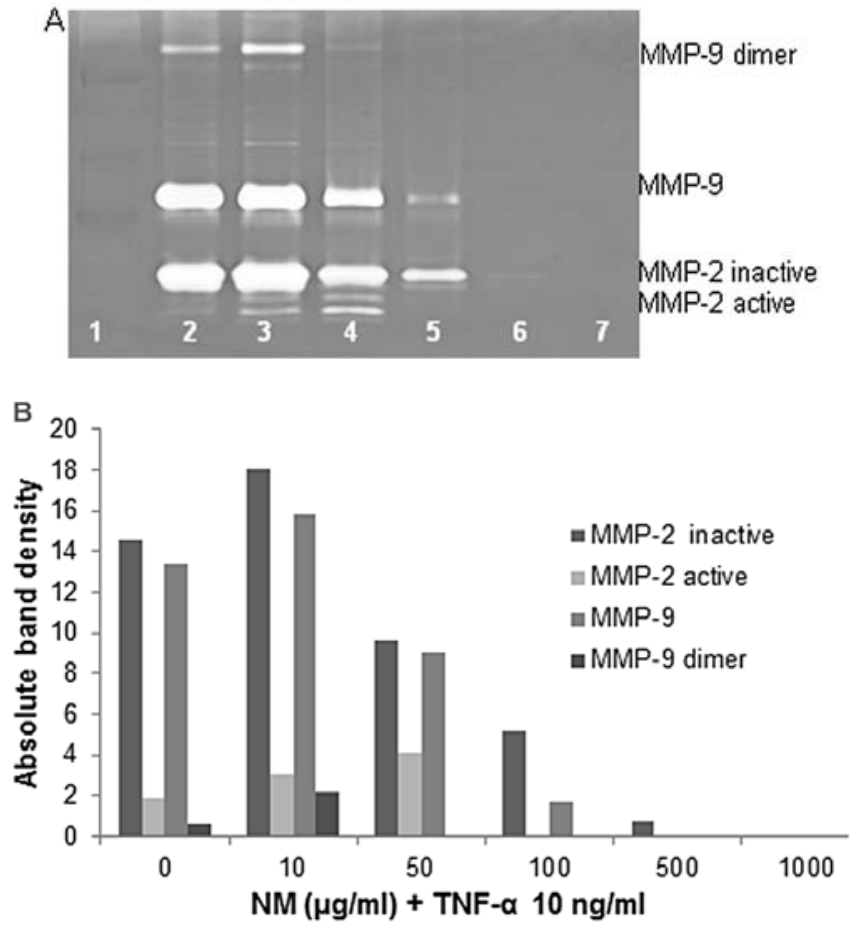

Figure 11. Effect of NM on TNF $\alpha$-treated fibrosarcoma HT-1080 MMP-2 and -9 secretions. Gelatinase zymogram (A) and densitometry analysis (B) of HT-1080 MMP-2 and -9 expression levels. Lane 1, Markers; 2, Control $(10 \mathrm{ng} / \mathrm{ml} \mathrm{TNF} \alpha) ; 3-7,10,50,100,500,1000 \mu \mathrm{g} / \mathrm{ml} \mathrm{NM}$ with TNF $\alpha$ (10 ng/ml).
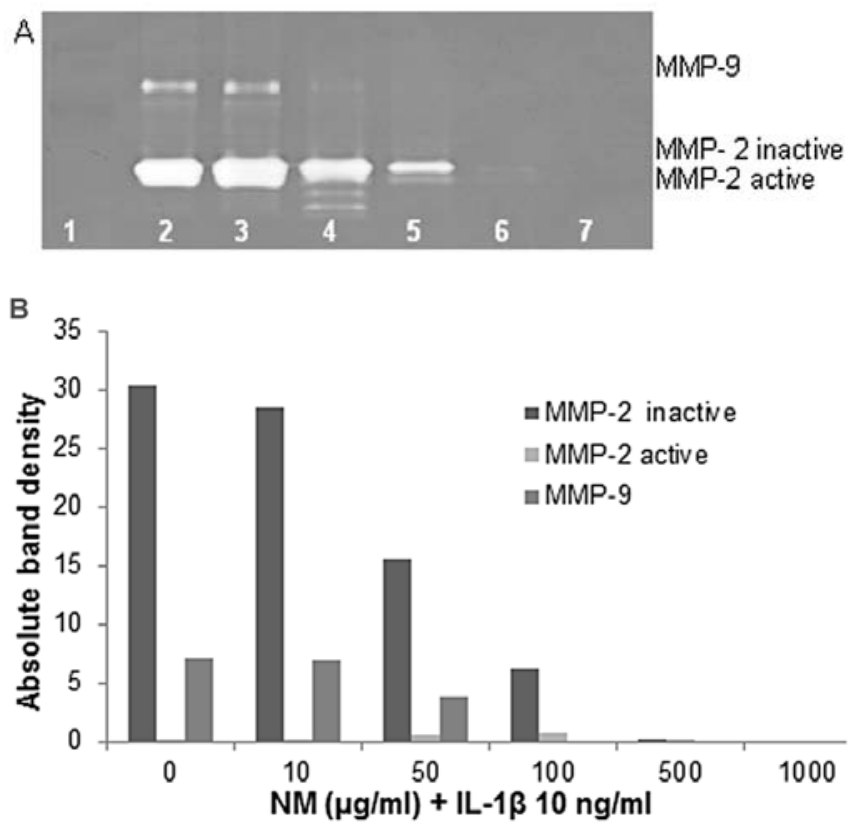

Figure 12. Effect of NM on IL-1 $\beta$ - treated fibrosarcoma HT-1080 MMP-2 and -9 secretions. Gelatinase zymogram (A) and densitometry analysis (B) of HT-1080 MMP-2 and -9 expression levels. Lane 1, Markers; 2, Control $(10 \mathrm{ng} / \mathrm{ml}$ IL-1 $\beta) ; 3-7,10,50,100,500,1000 \mu \mathrm{g} / \mathrm{ml} \mathrm{NM}$ with IL-1 $\beta(10 \mathrm{ng} / \mathrm{ml})$.

Effect of EGCG, the nutrient mixture and retinoic acid on MMP-2 and MMP-9 expression in liposarcoma $S W-872$ cell line treated with inducers. On gelatinase zymography, SW-872 cells demonstrated MMP-2 and strongly stimulated MMP-9 with PMA (100 ng/ml) treatment. EGCG inhibited
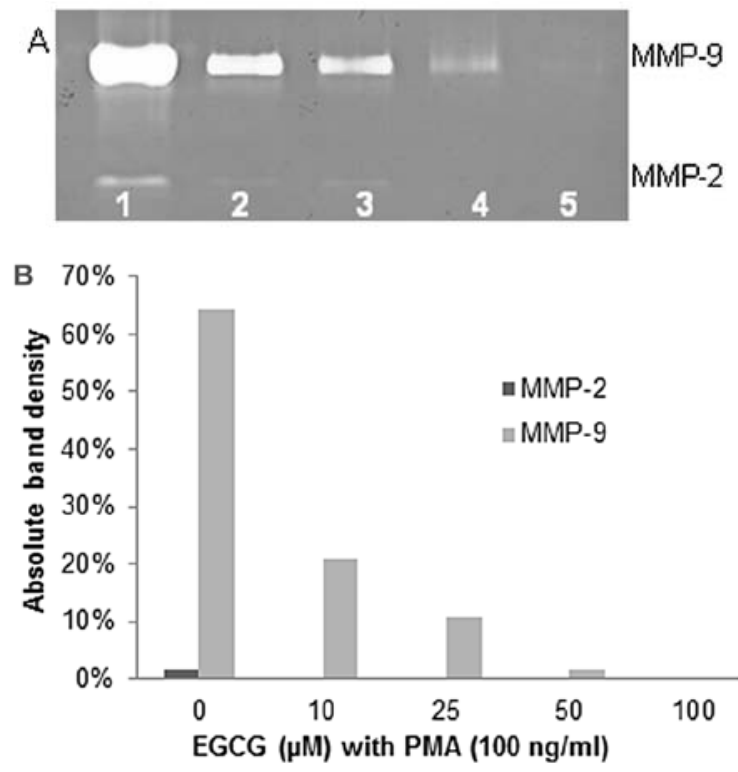

Figure 13. Effect of EGCG on PMA-treated liposarcoma SW-872 MMP-2 and -9 secretions. Gelatinase zymogram (A) and densitometry analysis (B) of SW-872 MMP-2 and -9 expression levels. Lane 1, Control (100 ng/ml PMA); 2-5, 10, 25, 50, $100 \mu$ M EGCG with PMA (100 ng/ml).
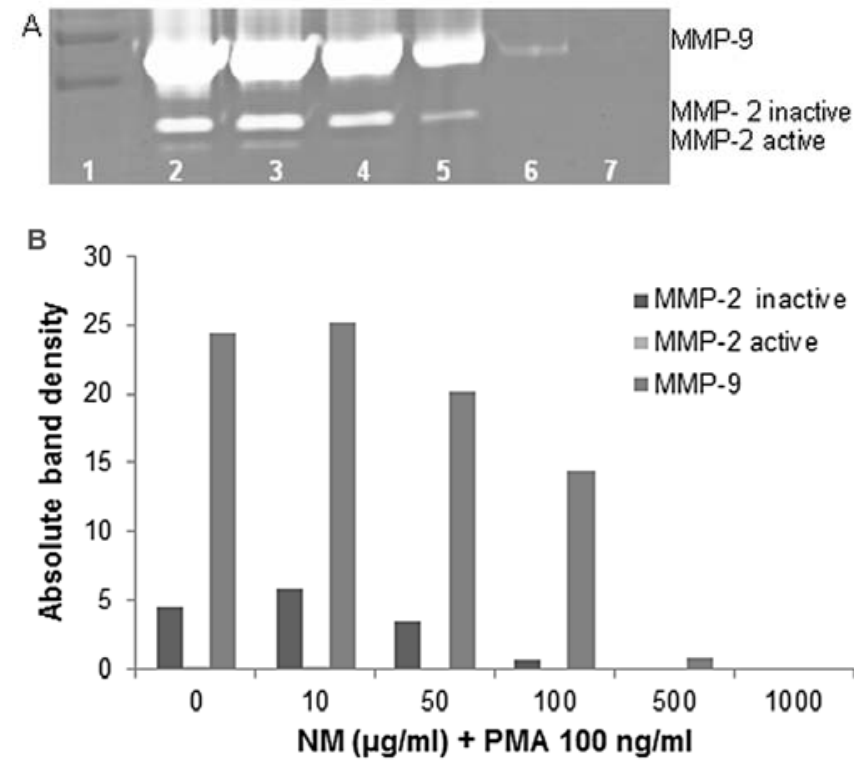

Figure 14. Effect of NM on PMA-treated liposarcoma SW-872 MMP-2 and -9 secretions. Gelatinase zymogram (A) and densitometry analysis (B) of SW-872 MMP-2 and -9 expression levels. Lane 1, Markers; 2, Control (100 ng/ml PMA); 3-7, 10, 50, 100, 500, $1000 \mu \mathrm{g} / \mathrm{ml} \mathrm{NM}$ with PMA $(100 \mathrm{ng} / \mathrm{ml})$.

both MMP-2 and -9 in a dose-dependent manner, with linear trends $\mathrm{R}^{2}=0.914$ and 0.787 , respectively; PMA $(100 \mathrm{ng} / \mathrm{ml})$ treated SW-872 cells showed MMP-2 and strongly enhanced MMP-9 expression, which were inhibited by EGCG in a dosedependent manner, with linear trends $\mathrm{R}^{2}=0.560$ and 0.782 , respectively, as shown in Fig. 13. NM treatment of SW-872 cells treated with PMA showed dose-dependent inhibition of MMP-2 and MMP-9, with linear trends $\mathrm{R}^{2}=0.820$ and 0.898 , respectively, as shown in Fig. 14. The effects of retinoic acid were not determined. 

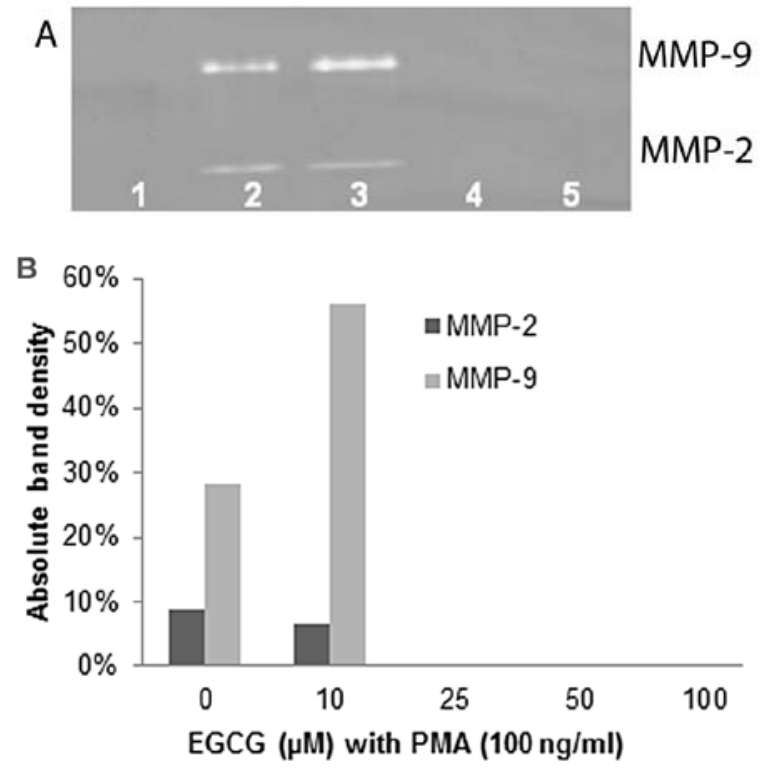

Figure 15. Effect of EGCG on PMA-treated synovial sarcoma SW-982 MMP-2 and -9 secretions. Gelatinase zymogram (A) and densitometry analysis (B) of SW-982 MMP-2 and -9 expression levels. Lane 1, Control (100 ng/ml PMA); 2-5, 10, 25, 50, $100 \mu$ M EGCG with PMA (100 ng/ml).

Effect of natural inhibitors: EGCG, the nutrient mixture and retinoic acid on MMP-2 and MMP-9 expression in synovial sarcoma $S W-892$ cell line treated with inducers. On gelatinase zymography, SW-892 cells showed strong MMP-2 expression and induction of MMP-9 with PMA $(100 \mathrm{ng} / \mathrm{ml})$ treatment. EGCG inhibited MMP-2 in a dose-dependent manner, with linear trend $\mathrm{R}^{2}=0.878$; PMA ( $\left.100 \mathrm{ng} / \mathrm{ml}\right)$-treated SW-982 cells showed MMP-2 and induced MMP-9 expression, which were inhibited by EGCG in a dose-dependent manner, with linear trends $\mathrm{R}^{2}=0.881$ and 0.459 , respectively, as shown in Fig. 15 . SW-982 cells treated with PMA showed dose-dependent inhibition of MMP-2 and MMP-9 expression with NM treatment, with linear trends, $\mathrm{R}^{2}=0.855$ and 0.694 , respectively, as shown in Fig. 16. Effects of retinoic acid were not determined.

\section{Discussion}

Experimental and clinical studies have shown a correlation between increased MMPs and tumor progression and metastasis $(6,7)$. Thus, knowledge of MMP regulation is of importance for developing therapeutic strategies. MMP expression is regulated at both pre- and post-transcriptional levels. Extracellular factors, including cytokines, growth factors and inducers and inhibitors, have been implicated in the regulation of MMP expression in different types of tumor cells $(15,16)$. Though few cytokine and growth factor studies have been conducted on sarcomas, some research has documented elevated serum levels of VEGF, IL-2 and bFGF in sera of patients with soft tissue sarcomas (17,18); VEGF serum levels correlated significantly with tumor size and histological grade (17). Serum cytokine levels significantly correlated with tumor size and grade suggesting involvement of cytokines in the progression of soft tissue sarcomas (14). Rutkowski et al found elevated cytokines and soluble cytokine receptors involved in bone destruction and bone formation in $46 \%$ of
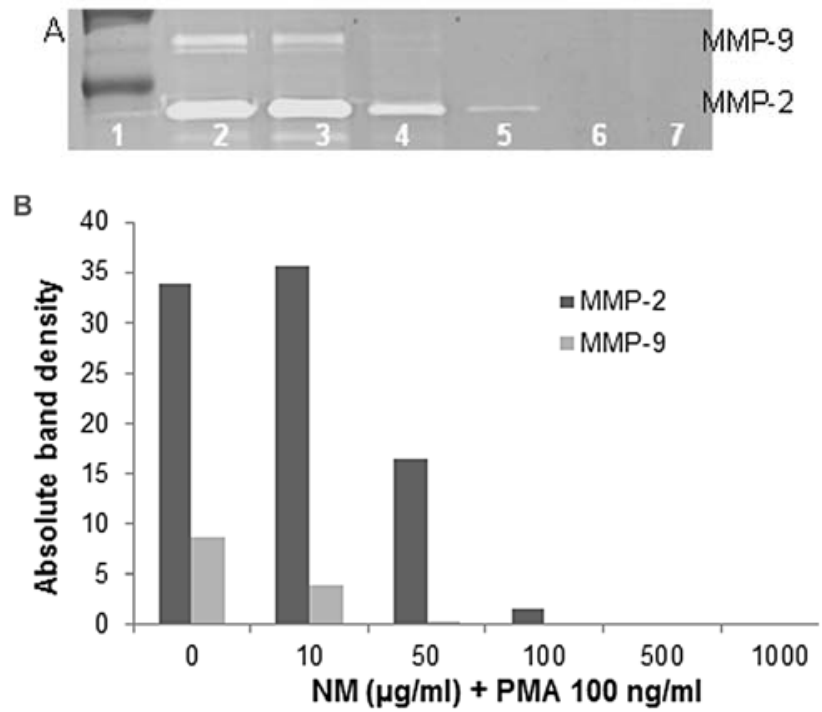

Figure 16. Effect of NM on PMA-treated synovial sarcoma SW-982 MMP-2 and -9 secretions. Gelatinase zymogram (A) and densitometry analysis (B) of SW-982 MMP-2 and -9 expression levels. Lane 1, Markers; 2, Control (100 ng/ml PMA); 3-7, 10, 50, 100, 500, $1000 \mu \mathrm{g} / \mathrm{ml} \mathrm{NM} \mathrm{with} \mathrm{PMA}$ (100 ng/ml).

adult bone sarcoma patients, suggesting they have an essential role in the progression of malignant bone tumors (19).

In this study, we compared MMP secretion patterns by cytokines, PMA and LPS in four adult sarcoma cell lines that express MMP-2 and MMP-9 to different extents. In addition, we investigated the effect of inhibitors doxycycline and EGCG and others, such as dexamethasone, retinoic acid and agents that affect transcription and translation levels, such as actinomycin-D and cyclohexamide. Furthermore, we tested a nutrition mixture that had inhibitory effects on MMP-2 and MMP-9 expression. We found that fibrosarcoma HT-1080, chondrosarcoma SW-1353, liposarcoma SW-872 and synovial sarcoma SW-982 normally expressed both MMP-2 and MMP-9. Treatment of all these cell lines with PMA strongly upregulated expression of MMP-9 in a dose-dependent manner. However, the effect on MMP-2 was variable; PMA-treated fibrosarcoma and chondrosarcoma cells showed slightly stimulated MMP-2 expression, while PMA showed no effect on liposarcoma expression of MMP-2 and inhibition of MMP-2 was seen in PMA treatment of synovial sarcoma. TNF- $\alpha$ had an inhibitory effect at $0.1-10 \mathrm{ng} / \mathrm{ml}$ and a stimulatory effect at $25 \mathrm{ng} / \mathrm{ml}$ on MMP-9 and an inhibitory effect at $0.1 \mathrm{ng} / \mathrm{ml}$ and stimulatory effect at $10-25 \mathrm{ng} / \mathrm{ml}$ on MMP-2 in chondrosarcoma SW1353 cells. In fibrosarcoma cells TNF- $\alpha$ strongly stimulated MMP-9 and slightly stimulated MMP-2. In liposarcoma cells, TNF- $\alpha$ strongly stimulated MMP-9 and showed slight up and down activity on MMP-2. Synovial sarcoma showed inhibition of MMP-2 with TNF- $\alpha$ and slight stimulation of MMP-9 at $10 \mathrm{ng} / \mathrm{ml}$. IL-1 $\beta$ stimulated MMP-9 and MMP-2 in chondrosarcoma cells, enhanced levels of both MMPs at $1 \mathrm{ng} / \mathrm{ml}$ but decreased levels at $25 \mathrm{ng} / \mathrm{ml}$ in fibrosarcoma, inhibited MMP-2 and enhanced MMP-9 at 1 and $10 \mathrm{ng} / \mathrm{ml}$ and downregulated at $25 \mathrm{ng} / \mathrm{ml}$ in liposarcoma cells. LPS showed slight stimulation of MMP-2 in chondrosarcoma and fibrosarcoma and slight inhibition of MMP-2 in liposarcoma, but no significant effect on MMP-9 in these cell lines. 
Doxycycline and EGCG inhibited MMP-2 and MMP-9 expression in a dose-dependent fashion in all cell lines tested. Sensitivity to doxycycline was nearly equivalent in MMP-2 expression, but fibrosarcoma expression of MMP-9 was significantly more sensitive to doxycycline than were the other cell lines. MMP- 2 expression was downregulated by $99 \%$ by doxycycline $100 \mu \mathrm{M}$ in chondrosarcoma by $100 \%$ in fibrosarcoma and by $99 \%$ in liposarcoma. MMP-9 expression was downregulated by doxycycline $100 \mu \mathrm{M}$ in chondrosarcoma and liposarcoma by 96 and $86 \%$, respectively, while fibrosarcoma MMP-9 expression was completely blocked at $25 \mu \mathrm{M}$. Sensitivity of cell lines to EGCG varied in MMP-2 expression, with total block at $25 \mu \mathrm{M}$ in synovial sarcoma, $50 \mu \mathrm{M}$ in fibrosarcoma and liposarcoma and $96 \%$ block in chondrosarcoma at $100 \mu \mathrm{M}$. PMA-induced MMP-9 expression was blocked by EGCG at $25 \mu \mathrm{M}$ in synovial sarcoma and $100 \mu \mathrm{M}$ in fibrosarcoma and virtually blocked at $100 \mu \mathrm{M}$ in chondrosarcoma and liposarcoma. Actinomycin-D, cyclohexamide, retinoic acid and dexamethasone inhibited MMP-2 and -9 in chondrosarcoma and fibrosarcoma cells.

The nutrition mixture inhibited MMP-2 and MMP-9 expression in a dose-dependent fashion in all PMA-treated cell lines. Synovial sarcoma was most sensitive to NM with block of MMP-2 at $500 \mu \mathrm{g} / \mathrm{ml}$ and MMP-9 at $100 \mu \mathrm{g} / \mathrm{ml}$. Liposarcoma showed block of MMP-2 at $500 \mu \mathrm{g} / \mathrm{ml}$ and MMP-9 at $1000 \mu \mathrm{g} / \mathrm{ml}$, while fibrosarcoma and chondrosarcoma showed block of MMP-2 at $1000 \mu \mathrm{g} / \mathrm{ml}$ and virtual block of MMP-9 at $1000 \mu \mathrm{g} / \mathrm{ml}$. MMP-2 and-9 expression of chondrosarcoma and fibrosarcoma cells treated with TNF- $\alpha 10 \mathrm{ng} / \mathrm{ml}$ were downregulated by NM treatment in a dose-dependent manner with MMP-2 block at $1000 \mu \mathrm{g} / \mathrm{ml} \mathrm{NM}$ and MMP-9 total block at $500 \mu \mathrm{g} / \mathrm{ml} \mathrm{NM}$ in fibrosarcoma and $99 \%$ block at $1000 \mu \mathrm{g} / \mathrm{ml}$ in chondrosarcoma. MMP-2 and-9 expression of chondrosarcoma and fibrosarcoma cells treated with IL-1 $\beta$ $10 \mathrm{ng} / \mathrm{ml}$ were downregulated by $\mathrm{NM}$ treatment in a dosedependent manner with MMP-2 block at $1000 \mu \mathrm{g} / \mathrm{ml} \mathrm{NM}$ and MMP-9 total block at $100 \mu \mathrm{g} / \mathrm{ml} \mathrm{NM}$ in fibrosarcoma and at $1000 \mu \mathrm{g} / \mathrm{ml}$ in chondrosarcoma.

The nutrition mixture studied, which contains lysine, proline, ascorbic acid and green tea extract among other micronutrients, has been shown to have anti-tumor and anti-invasive potential in vivo and in vitro (20). Of interest, a previous study demonstrated significant correlation between NM inhibition of Matrigel invasion and NM modulation of the MMP-2 and -9 activities of the sarcoma cell lines studied (21). Significant negative correlations were found between NM modulation of Matrigel invasion inhibition and MMP-2 secretion with fibrosarcoma HT-1080 ( $r=-0.911)$, chondrosarcoma SW-1353 $(r=-0.942)$, liposarcoma SW-872 $(r=-0.957)$ and synovial sarcoma SW-982 $(r=-0.878)$. Previous in vivo studies of the dietary effects of NM $0.5 \%$ on xenograft tumor growth of fibrosarcoma and synovial sarcoma cells in nude mice support these results in that they demonstrated significant inhibition of xenograft tumor growth: $59 \%, \mathrm{p}=0.0005$ in fibrosarcoma HT-1080 xenografts (22) and 44\%, $\mathrm{p}=0.01$ in synovial sarcoma Hs 701.T xenografts (23).

NM was designed by focusing on physiological targets in cancer progression and metastasis as documented in clinical and experimental studies. The nutrient mixture was formulated by selecting nutrients that act on critical physiological targets in cancer progression and metastasis, as documented in both clinical and experimental studies. Combining these micronutrients expands metabolic targets, maximizing biological impact with lower doses of components. A previous study of the comparative effects of NM, green tea extract and EGCG on inhibition of MMP-2 and MMP-9 secretion of different cancer cell lines with varying MMP secretion patterns, revealed the superior potency of NM over GTE and EGCG at equivalent doses (24). These results can be understood from the more comprehensive treatment offered by the combination of nutrients in NM over individual components of NM since MMP-2 and MMP-9 are mediated by differential pathways.

Optimal ECM structure depends upon adequate supplies of ascorbic acid and the amino acids lysine and proline to ensure proper synthesis and hydroxylation of collagen fibers. In addition, lysine contributes to ECM stability as a natural inhibitor of plasmin-induced proteolysis $(25,26)$. Manganese and copper are also essential for collagen formation. There is considerable documentation of the potency of green tea extract in modulating cancer cell growth, metastasis, angiogenesis and other aspects of cancer progression (27-31). N-acetyl cysteine and selenium have demonstrated inhibition of tumor cell MMP-9 and invasive activities, as well as migration of endothelial cells through ECM (32-34). Ascorbic acid demonstrates cytotoxic and antimetastatic actions on malignant cell lines (35-39) and cancer patients have been found to have low levels of ascorbic acid $(40,41)$. Low levels of arginine, a precursor of nitric oxide (NO), can limit the production of NO, which has been shown to predominantly act as an inducer of apoptosis (42).

In conclusion, our results show that cytokines and inhibitors regulate MMP-2 and MMP-9 expression in adult sarcoma cell lines, suggesting the clinical value of targeting these proteases for management of sarcomas and their pathogenesis.

\section{Acknowledgements}

This study was funded by Dr. Rath Health Foundation (Santa Clara, CA), a non-profit organization.

\section{References}

1. American Cancer Society: Adult soft tissue cancer. What are the key statistics about soft tissue sarcomas? http:/www.cancer. org/cancer/sarcoma-adultsofttissuecancer/detailedguide/sarcomaadult-soft-tissue-cancer-key-statistics. Last revised October 2, 2012. Accessed January 21, 2013.

2. American Cancer Society: Bone cancer. What are the key statistics about bone cancer? http://www.cancer.org/cancer/ bonecancer/detailedguide/bone-cancer-key-statistics. Last revised November 29, 2012. Accessed January 21, 2013.

3. Papagelopoulos PJ, Galanis E, Frassica FJ, Sim FH, Larson DR and Wold LE: Primary fibrosarcoma of bone. Outcome after primary surgical treatment. Clin Orthop Relat Res 373: 88-103, 2000.

4. Benassi MS, Gamberi G, Magagnoli G, Molendini L, Ragazzini P, Merli M, Chiesa F, Balladelli A, Manfrini M, Bertoni F, Mercri M and Picci P: Metalloproteinase expression and prognosis in soft tissue sarcomas. Ann Oncol 12: 75-80, 2001.

5. Nelson AR, Fingleton B, Rothenberg ML and Matrisian LM: Matrix metalloproteinases: biologic activity and clinical implications. J Clin Oncol 18: 1135-1149, 2000.

6. Liotta LA, Tryggvason K, Garbisa A, Hart I, Foltz CM and Shafie S: Metastatic potential correlates with enzymatic degradation of basement membrane collagen. Nature 284: 67-68, 1980.

7. Stetler-Stevenson WG: The role of matrix metalloproteinases in tumor invasion, metastasis, and angiogenesis. Surg Oncol Clin N Am 10: 383-392, 2001. 
8. Stetler-Stevenson WG: Type IV collagenases in tumor invasion and metastasis. Cancer Metastasis Rev 9: 289-303, 1990.

9. Sato T, Sakai T, Noguchi Y, Takta M, Hirakawa S and Ito A: Tumor-stromal cell contact promotes invasion of human uterine cervical carcinoma cells by augmenting the expression and activation of stromal matrix metalloproteinases. Gynecol Oncol 92: 47-56, 2004.

10. Pyke C, Kristensen P, Ralfkiaer E, Gröndahl-Hansen J, Eriksen J, Blasi F and Danø K: Urokinase-type plasminogen activator is expressed in stromal cells and its receptor in cancer cells at invasive foci in human colon adenocarcinomas. Am J Pathol 138 1059-1067, 1991.

11. Harvey P, Clark IM, Jourand MC, Warn RM and Edwards DR: Hepatocyte growth factor/scatter factor enhances the invasion of mesothelioma cell lines and the expression of matrix metalloproteinases. Br J Cancer 83: 1147-1153, 2000.

12. Liu Z, Ivanoff A and Klominek J: Expression and activity of matrix metalloproteases in human malignant mesothelioma cell lines. Int J Cancer 91: 638-643, 2001.

13. Vincenti MP, White LA, Schroen DJ, Benbow U and Brinckerhoff CE: Regulating expression of the gene for matrix metalloproteinase-1 (collagenase): mechanisms that control enzyme activity, transcription and mRNA stability. Crit Rev Eukaryot Gene Expr 6: 391-411, 1996

14. Rutkowski P, Kaminska J, Kowalska M, Ruka W and Steffen J: Cytokine and cytokine receptor serum levels in soft tissue sarcoma patients: correlations with clinico-pathological features and prognosis. Int J Cancer 100: 463-471, 2002.

15. Ray JM and Stetler-Stevenson WG: The role of matrix metalloproteinase and their inhibitors in tumour invasion, metastasis and angiogenesis. Eur Respir J 7: 2062-2072, 1994.

16. Apodaca G, Rutka JT, Bouhana K, Berens ME, Giblin JR Rosenblum ML, McKerrow JH and Banda MJ: Expression of metalloproteinases and metalloproteinase inhibitors by fetal astrocytes and glioma cells. Cancer Res 50: 2322-2329, 1990

17. Linder C, Linder S, Munck-Wickland E and Strander H: Independent expression of serum vascular endothelial growth factor (VEGF) and basic fibroblast growth factor (bFGF) in patients with carcinoma and sarcoma. Anticancer Res 18: 2063-2068, 1998.

18. Graeven U, Andre N, Achilles E, Zornig C and Schmeigel W: Serum levels of vascular endothelial growth factor and basic fibroblast growth factor in patients with soft-tissue sarcoma. J Cancer Res Clin Oncol 125: 577-581, 1999.

19. Rutkowski P, Kaminska J, Kowalska M, Ruka W and Steffen J: Cytokine and cytokine receptor serum levels in adult bone sarcoma patients: correlations with local tumor extent and prognosis. J Surg Oncol 84: 151-159, 2003.

20. Niedzwiecki A, Roomi MW, Kalinovsky T and Rath $M$ Micronutrient synergy - a new tool in effective control of metastasis and other key mechanisms of cancer. Cancer Metastasis Rev 29: 529-543, 2010.

21. Roomi MW, Monterrey JC, Kalinovsky T, Niedzwiecki A and Rath M: Inhibition of invasion and MMPs by a nutrient mixture in human cancer cell lines: a correlation study. Exp Oncol 32: 243-248, 2010.

22. Roomi MW, Ivanov V, Kalinovsky T, Rath M and Niedzwiecki A: In vivo and in vitro antitumor effect of ascorbic acid, lysine, proline, arginine and green tea extract on human fibrosarcoma cells HT-1080. Med Oncol 23: 105-112, 2006.

23. Roomi MW, Ivanov V, Kalinovsky T, Niedzwiecki A and Rath M: In vitro and in vivo anti-tumor effect of a nutrient mixture containing ascorbic acid, lysine, proline and green tea extract on human synovial sarcoma cancer cells. JANA 9: 2, 2006.

24. Roomi MW, Monterrey JC, Kalinovsky T, Rath M and Niedzwiecki A: Comparative effects of EGCG, green tea and a nutrient mixture on the patterns of MMP-2 and MMP-9 expression in cancer cell lines. Oncol Rep 24: 747-757, 2010.
25. Rath M and Pauling L: Plasmin-induced proteolysis and the role of apoprotein(a), lysine and synthetic analogs. Orthomolecular Med 7: 17-23, 1992.

26. Sun Z, Chen YH, Wang P, Zhang J, Gurewich V, Zhang P and Liu JN: The blockage of high-affinity lysine binding sites of plasminogen by EACA significantly inhibits prourokinase-induced plasminogen activation. Biochem Biophys Acta 1596: 182-192, 2002.

27. Valcic S, Timmermann BN, Alberts DS, Wachter GA, Krutzsch M, Wymer J and Guillen JM: Inhibitory effect of six green tea catechins and caffeine on the growth of four selected human tumor cell lines. Anticancer Drugs 7: 461-468, 1996.

28. Mukhtar $\mathrm{H}$ and Ahmed N: Tea polyphenols: prevention of cancer and optimizing health. Am J Clin Nutr 71 (Suppl 6): 1698-1704, 2000.

29. Yang GY, Liao J, Kim K, Yurtow EJ and Yang CS: Inhibition of growth and induction of apoptosis in human cancer cell lines by tea polyphenols. Carcinogenesis 19: 611-616 1998

30. Taniguchi S, Fujiki H, Kobayashi H, Go H, Miyado K, Sadano H and Shimikawa R: Effect of (-) epigallocatechin gallate, the main constituent of green tea, on lung metastasis with mouse B16 melanoma cell lines. Cancer Lett 65: 51-54, 1992.

31. Hara Y: Green Tea: Health Benefits and Applications. Marcel Dekker, New York, Basel, 2001.

32. Kawakami S, Kageyama Y, Fujii Y, Kihara K and Oshima H: Inhibitory effects of $\mathrm{N}$-acetyl cysteine on invasion and MMP 9 production of T24 human bladder cancer cells. Anticancer Res 21: 213-219, 2001.

33. Morini M, Cai T, Aluigi MG, Noonan DM, Masiello L, De Floro S, D'Agostinin F, Albini A and Fassima G: The role of the thiol $\mathrm{N}$-acetyl cysteine in the prevention of tumor invasion and angiogenesis. Int J Biol Markers 14: 268-271, 1999.

34. Yoon SO, Kim MM and Chung AS: Inhibitory effects of selenite on invasion of HT 1080 tumor cells. J Biol Chem 276: 20085-20092, 2001

35. Naidu KA, Karl RC and Coppola D: Antiproliferative and proapoptotic effect of ascorbyl stearate in human pancreatic cancer cells: association with decreased expression of insulinlike growth factor 1 receptor. Dig Dis Sci 48: 230-237, 2003.

36. Anthony HM and Schorah CJ: Severe hypovitaminosis C in lung-cancer patients: The utilization of vitamin $\mathrm{C}$ in surgical repair and lymphocyte-related host resistance. Br J Cancer 46: 354-367, 1982

37. Maramag C, Menon M, Balaji KC, Reddy PG and Laxmanan S: Effect of vitamin $C$ on prostate cancer cells in vitro: effect on cell number, viability and DNA synthesis. Prostate 32: 188-195, 1997.

38. Koh WS, Lee SJ, Lee H, Park C, Park MH, Kim WS, Yoon SS, Park K, Hong SI, Chung MH and Park CH: Differential effects and transport kinetics of ascorbate derivatives in leukemic cell lines. Anticancer Res 8: 2487-2493, 1998.

39. Chen Q, Espey MG, Krishna MC, Mitchell JB, Corpe CP, Buettner GR, Shacter E and Levine M: Pharmacologic ascorbic acid concentrations selectively kill cancer cells: action as a pro-drug to deliver hydrogen peroxide to tissues. Proc Natl Acad Sci USA 102: 13604-13609, 2005.

40. Nunez C, Ortiz de Apodaca Y and Ruiz A: Ascorbic acid in the plasma and blood cells of women with breast cancer. The effect of consumption of food with an elevated content of this vitamin. Nutr Hosp 10: 368-372, 1995 (In Spanish).

41. Kurbacher CM, Wagner U, Kolster B, Andreotti PE, Krebs D and Bruckner HW: Ascorbic acid (vitamin C) improves the antineoplastic activity of doxorubicin, cisplatin and paclitaxel in human breast carcinoma cells in vitro. Cancer Lett 103: 183-189, 1996.

42. Cooke JP and Dzau VJ: Nitric oxide synthase: Role in the genesis of vascular disease. Annu Rev Med 48: 489-509, 1997. 